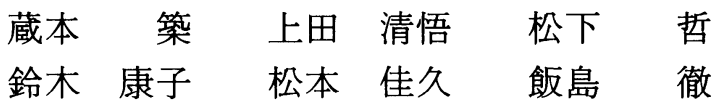

\footnotetext{
＜要 約> 老年者連続剖検 3,236 例について血清コレステロール值と動脈硬化, 脳心合併症について比 較検討した。

1. 血清コレステロール值は80歳以後に減少を示し, 各年代共女性は男性より高値を示した。

2. 血清コレステロール值の上昇は男女とも冠動脈硬化を促進したが同一コレステロール值では男性 が高度であった。この冠動脈硬化の促進効果は高血圧群では著明であったが正常血圧群では認められな かった、脳動脈捛よび大腿動脈の硬化にはコレステロールは影響を与えなかった。大動脈硬化はコレス テロール $160 \mathrm{mg} / \mathrm{d} l$ 未満で軽度であった。

3. 冠硬化の促進を反映してコレステロール值の上昇は心筋梗塞の頻度を増加させたが, この増加も高 血圧群での久認められ，正常血圧群では明らかでなかった。コレステロール値と脳梗塞の頻度の間には 相関は認められなかった。

老年者では高血圧に揖いてのみ高コレステロール血症が心筋梗塞のリスクとなり得ることを示した。
}

Key words：コレステロール, 高血圧, 動脈硬化, 心筋梗塞, 脳梗塞

中壮年に於ける高コレステロール血症と冠動脈疾患 の間に正相関が見られることは現在ほぼ一致した成績 であるが，脳血管障害については必ずしも一定の見解 が得られていない1) 4)。一方老年者に於ては高コレス テロール血症が冠疾患の危険因子とはならないとする もの ${ }^{5) 6}$ ，また老年者に於ても中壮年と同様に虚血性心 疾患を増加させるとの相異なる成績が見られてい る ${ }^{7) \sim 9)}$.

老年者では血清コレステロールは加齢と共に低下寸 るとされており ${ }^{10)}$ ，老年者の高脂血症を治療すべきか 否かについても現在明らかな指針は見られていない。 一方，老年者では高血圧が約半数に見られ，高血圧と 高脂血症の合併による動脈硬化, 虚血性心疾患の促進 が11) 15), 老年者においても認められるか否かも重大な 問題である.

以上の問題を解明するため老年者連続剖検 3236 例に ついて入院時血清コレステロール値と脳動脈, 冠動脈, 大動脈, 大腿動脈の動脈硬化の程度, および脳梗塞, 心筋梗塞との関連について検討し，更に高血圧合併の 影響についても分析を行った。

K. Kuramoto, S. Ueda, S. Matsushita, Y. Suzuki, Y.

Matsumoto, T. Iijima：東京都老人医療センター

受付日：1990。7.25, 採用日：1990。 8.16

\section{対象及び方法}

対象は1972年より1986年までの東京都老人医療セン ター連続剖検例 3,236 例である。血清コレステロール値 は入院時のものを採用した。重篤な疾患発症前の血圧 レベルにより収縮期血圧 $160 \mathrm{mmHg}$ 以上拡張期血圧 90 $\mathrm{mmHg}$ 未満を収縮期高血圧とし，拡張期血圧90 $\mathrm{mmHg}$ 以上を抬張期高血圧とした。 この両者を高血圧 とし収縮期血圧 $160 \mathrm{mmHg}$ 末満, かつ拡張期血压 90 $\mathrm{mmHg}$ 未満を正常血圧とした。

動脈硬化の程度は肉眼的観察により大動脈では粥状 硬化の占める面積と潰瘍, 石灰化などの複雑病変の程 度により, 脳動脈では粥状硬化の分布と内腔狭窄度に 上り高度, 中等度, 軽度, 微少の 4 段階に分類した。 冠動脈では前下行枝, 回旋枝, 右冠動脈三枝の狭窄度 を $100 \%$ 5，75\%を $4 ， 50 \%$ 3，25\%を 2 ，狭窄を 伴わない硬化巣のみを 1 ，なしを 0 として評点を与光， その合計狭窄度により13〜15を高度, 9 12を中等度, $5 \sim 8$ を軽度, 0 〜 4 を微少とした。

脳梗塞は各大脳動脈全域の病巣に相当するものまた は脳底動脈血栓を大型, 径 $0.5 \mathrm{~cm}$ 以内の病変を小型, その中間のものを中型病変とした。心竻梗塞は長径が $2 \mathrm{~cm}$ 以上の虚血性病変とし, $5 \mathrm{~cm}$ 以上を大型, $3 \sim 4.9$ $\mathrm{cm}$ を中型, $2 \sim 2.9 \mathrm{~cm}$ を小型とした。 
統計的解析には Student $の \mathrm{t}$ 検定及び Wilcoxon の 順位和検定を用いた。

\section{成 績}

1. 血清コレステロール値の年齢, 性別分布

コレステロール值は男女共 $60 ， 70$ 歳代には差を認め ないが，80歳代以後は減少を示し，60，70歳代間を除 き各年代間に有意差を認めた(表 1 )。各年代において 女性は男性より有意に高値を示し, 全体の平均値士標 準偏差は男性 $155.5 \pm 50.3 \mathrm{mg} / \mathrm{d} l$, 女性 $176.1 \pm 57.2$ $\mathrm{mg} / \mathrm{d} l$ であった。

年次別推移では男女共 1980 年代より約 $10 \mathrm{mg} / \mathrm{d} l$ の

表 1 対象の年齢, 性別コレステロール值

\begin{tabular}{r|r|r|r|r|r}
\hline & \multicolumn{1}{|c|}{60} & \multicolumn{1}{c|}{70} & \multicolumn{1}{c|}{80} & \multicolumn{1}{c|}{90} & Total \\
\hline \multirow{3}{*}{$\mathrm{M}$} & 160.5 & 159.3 & 151.9 & 132.7 & 155.5 \\
& 53.6 & 50.4 & 48.5 & 41.9 & 50.3 \\
& 256 & 745 & 554 & 91 & 1646 \\
\hline \multirow{3}{*}{$\mathrm{F}$} & 182.1 & 183.7 & 171.2 & 160.7 & 176.1 \\
& 59.0 & 65.3 & 50.0 & 41.6 & 57.2 \\
& 182 & 620 & 608 & 180 & 1590 \\
\hline & 169.4 & 170.4 & 162.0 & 151.3 & 165.6 \\
$\mathrm{~T}$ & 56.8 & 58.9 & 50.2 & 43.7 & 54.8 \\
& 438 & 1365 & 1162 & 271 & 3236 \\
\hline
\end{tabular}

$\mathrm{M}$ : 男性, F：女性, $\mathrm{T}$ : 計

上段より平均値, 標準偏差, 例数を示す
上昇を示した.

2. コレステロールと動脈硬化

血清コレステロール值を $160 \mathrm{mg} / \mathrm{d} l$ 未満, $160 \mathrm{mg} / \mathrm{d} l$ 以上 $199 \mathrm{mg} / \mathrm{d} l$ 以下, $200 \mathrm{mg} / \mathrm{d} l$ 以上 $229 \mathrm{mg} / \mathrm{d} l$ 以下, $230 \mathrm{mg} / \mathrm{d} l$ 以上の 4 群に分け, 各動脈に於ける動脈硬 化の程度を比較した (図 1，2）. 大動脈では $160 \mathrm{mg} / \mathrm{d} l$ 未満のものは他の 3 群に比し動脈硬化の程度が軽度で あったが $160 \mathrm{mg} / \mathrm{d} l$ 以上の 3 群間には差を認めなかっ た。大腿動脈, 脳動脈においてはコレステロール值と 動脈硬化の間に一定の傾向を認めなかった。冠動脈で はコレステロール値の上昇につれて冠硬化の有意の進 展を認めた。な摙冠硬化は同一コレステロールの群で は男性が女性に比し高度であった。しかしコレステ ロールの上昇による冠硬化の進展は男女ともに認めら れた。

コレステロールの上昇による冠硬化の進展は正常血 圧では認められず, 高血圧でのみ認められた（図 3 ）。 この冠硬化進展に対する高血圧の合併の影響は収縮期 高血圧に於ても拡張期高血圧と同様に認められ，同じ コレステロール值では同程度の冠硬化を示した。

\section{3. コレステロールと心筋梗塞, 脳梗塞}

心筋梗塞の頻度は血清コレステロール値の上昇につ れて増加を示し, 特にコレステロール $230 \mathrm{mg} / \mathrm{d} l$ 以上 では $200 \mathrm{mg} / \mathrm{d} l$ 未満のものに比べ有意に多く見られ た. 全心筋梗塞に占める大型心筋梗塞の割合もコレス テロール值の上昇と共に増加した。一方脳梗塞の頻度

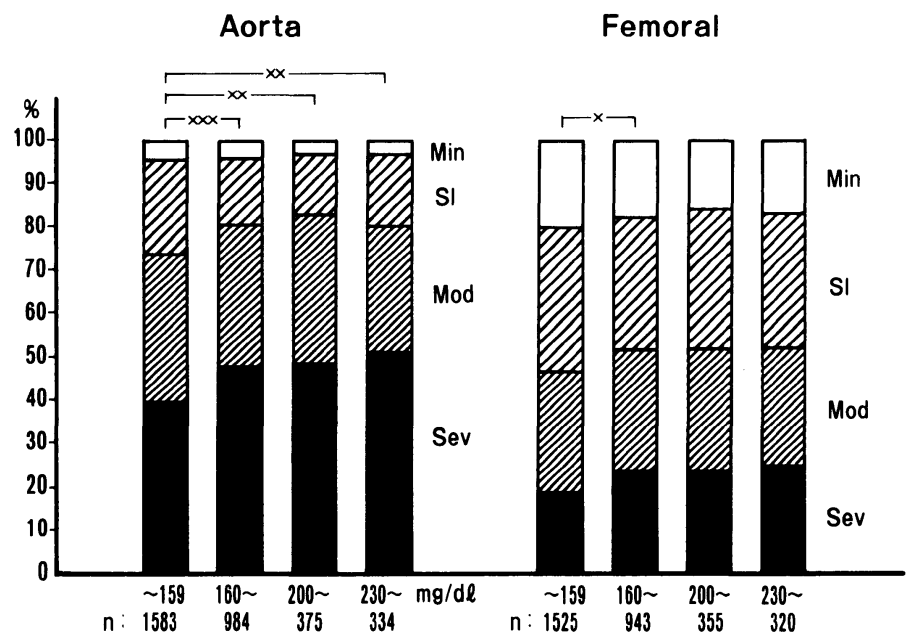

図 1 コレステロールと大動脈および大腿動脈硬化

Sev : 高度, Mod: 中等度, S1: 軽度, Min：微少, $x: \mathrm{p}<0.05, \times \times: \mathrm{p}<$ $0.01, \times \times \times: \mathrm{p}<0.001$ 


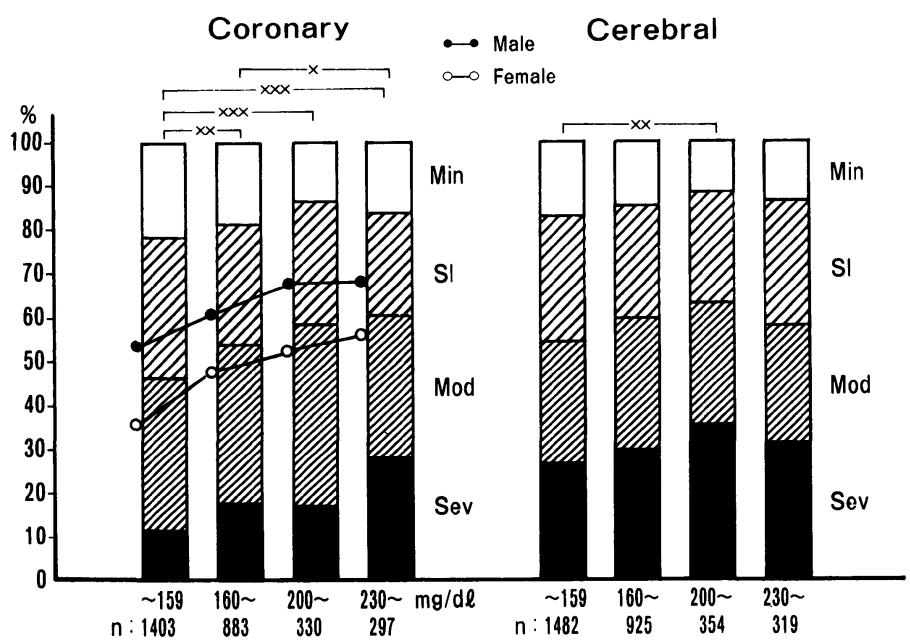

図 2 コレステロールと冠動脈および脳動脈硬化. 符号は図 1 と同じ，冠動脈硬化の 実線は男女別の中等度以上硬化の頻度を示す。

Normoteneion

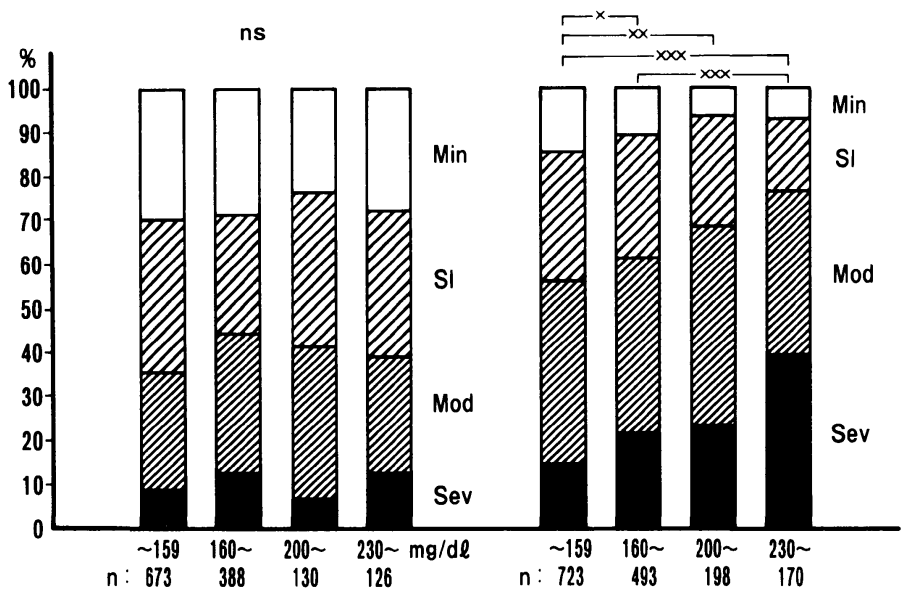

図 3 コレステロールと冠動脈硬化に対する高血圧の影響．符号は図 1 と同じ，ns： 有意差なし

は血清コレステロール值との間に一定の相関を認めな かった(図 4 ). このコレステロール値の上昇に伴ら心 筋梗塞の増加は, 冠硬化と同様に高血圧を伴う群にお いてのみ認められ, 正常血圧群では血清ュレステロー ルと心筋梗塞との相関は認められなかった（図 5 ).

\section{考 察}

老年者連続剖検例に於ける血清コレステロール値と 動脈硬化, 脳・ 心合併症の対比から, 老年者に於ても コレステロール值の上昇は冠硬化を促進し, 心筋梗塞
を増加させるがこの促進は高血圧が合併する時にのみ 有意なものとなった。一方脳動脈硬化, 脳梗塞にはコ レステロール上昇は影響を示さなかった。

コレステロール值と虚血性心疾患の間に正の相関の 見られる事は一致した所見であるが1) 4), 脳梗塞につ いては正相関を示すものと ${ }^{1)}$ ，相関を認めないものが 見られる4!.しかしこれらの多くは中壮年者が対象で あり，老年者について Anderson ら5゙はレステロー ル上昇は死亡率を上昇させないこと，また Kannel ら も老年女性ではコレステロールは冠疾患のリスクとな 


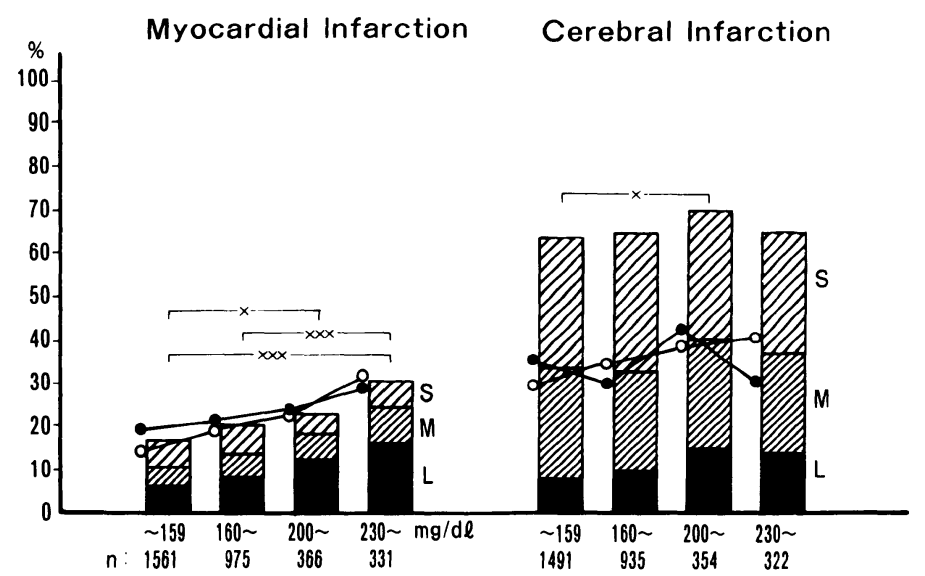

図 4 コレステロールと心筋梗塞および脳梗塞。符号は図 1, 図 2 と同じ, L : 大型, $\mathrm{M}$ : 中型, $\mathrm{S}$ : 小型病変, 心筋梗塞の実線は全例の男女別頻度, 脳梗塞の実線は中型 以上の病変の男女別頻度を示す。

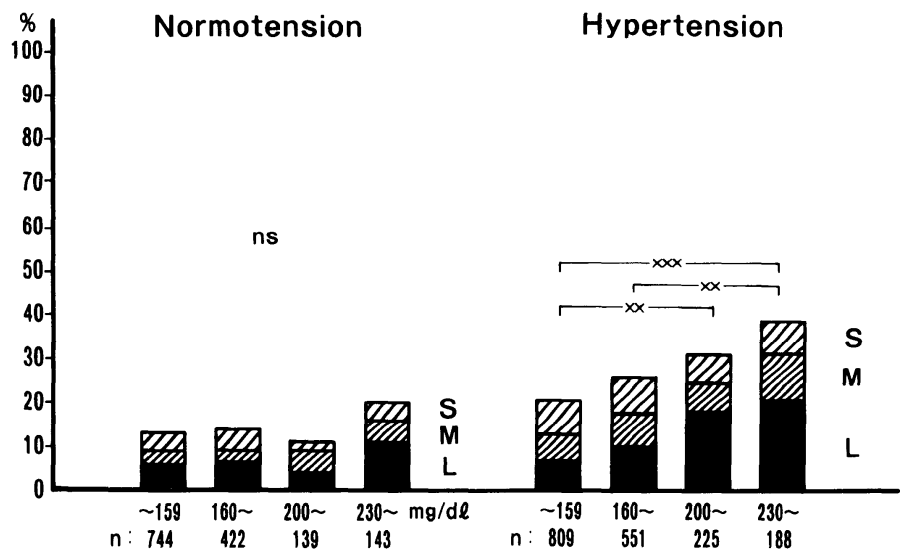

図 5 コレステロールと心筋梗塞に対する高血厈の影響. 符号は図 4 と同じ

るが, 老年男性ではリスクにはならないとしている. 一方 Castelli ら ${ }^{8)}$ は65歳以上に扎いてもコレステロー ル値が $294 \mathrm{mg} / \mathrm{d} l$ 以上では虚血性心疾患のリスクであ ることを示した. Benfanteら》はホノルル研究に於て コレステロール値上昇の相対的リスクは60歳未満 1.64 に対し60歳以上で 1.68 と差を認めず老年者でも同様な 虚血性心疾患の増加を示すが, 同一コレステロール值 では老年者の方に虚血性心疾患が多いとしている. Agner ら ${ }^{9)}$ 女70歳代に於けるコレステロール上昇によ り心血管疾患の増加を示した。

年齢と血清コレステロール值について, 我われの成 績は男女共80歳代以上で低下を示し，各年㛔に於ては いずれも女性が高值を示した。高龄になると血清コレ ステロール値が減少することは一致した成績が見られ
るが，関本ら ${ }^{10)} は 60$ 歳以上で下降を認め, Kannel らは 男性は60歳以上, 女性は70歳以上でその低下を認めて いる. 我々の血清コレステロール値は関本らの我国の 平均値に比し全般的に低值を示しているが，これは入 院時の値をとった為と思われる，冠硬化が女性に軽度 であることは閉経前には estrogenの関与が知られて いるが，この性差は高齢女性でコレステロール值が高 いにも拘らず同様に認められた。

高コレステロール血症に他の危険因子が合併すると 虚血性心疾患の頻度が著明に増加することが知られて おり ${ }^{11 \sim 15)}$, Kannel ら ${ }^{13)}$ は 2 倍にAssman ら ${ }^{11)}$ 15倍も増加するとしている。我われは利尿薬を主とし た降圧治療によりコレステロールを始めとする諸危険 因子の増加と共に虚血性心疾患が増加することを示し 
た ${ }^{14)}$. Chobanian ら ${ }^{15)}$ は高脂血症の Watanabe rabbit を高血圧にすると動脈硬化がより進展することを示し ている，老年者においては高血圧が約半数に見られる が，我々の成績ではコレステロール上昇による冠硬化 促進，心筇梗塞増加は高血圧合併例においての久見ら れ，正常血圧群では見られなかった，老年者に拈ける 高血圧の意義の大きいことを示すものである。

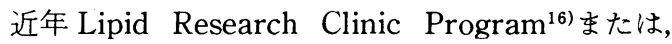
Helsinki Heart Study ${ }^{17)}$ などに於て抗脂血症薬の治療 により冠疾患の発症を防止出来ることが報告されてい る。しかしこれらはいずれも中壮年を対象とした治験 であり老年者に於ける成績は不明である。中津ら ${ }^{18)}$ は コレステロール值の改善により65歳以下では生存率の 低下を抑制していたが，65歳以上ではその抑制効果が 見られなかったとしている。老年者の高脂血症治療の 有用性についてはな打今後の研究が必要である。

本研究は老化防止研究委員会の研究費により行った。

\section{文献}

1) Iso $H$, Jacobs $D R$, Wentworth $D$, Neaton JD, Cohen JD, Iso $\mathrm{H}$, Jacobs $\mathrm{DR}$, Wentworth $\mathrm{D}$, Neaton JD, Cohen JD, for the MRFIT research group: Serum cholesterol levels and six-year mortality from stroke in 350,977 men screened for the multiple risk factor intervention trial. New Engl J Med 320 : 904-910, 1989.

2) Kromhout D, Bosschieter EB, Drijver M, Coulander CL: Serum cholesterol and 25-Year incidence of and mortality from myocardial infarction and cancer. The Zutphen Study. Arch Intern Med 148 : 1051-1055, 1988.

3) Martin MJ, Hulley SB, Browner WS, Kuller LH, Wentworth D: Serum cholesterol, blood pressure, and mortality: Implications from a cohort of 361, 662 men. Lancet ii : 933-936, 1986.

4）垂井清一郎：日本人に招ける高脂血症とその合併 症. 動脈硬化 18:1-16, 1990.

5) Anderson KM, Castelli WP, Levy D: Cholesterol and Mortality, 30 years of follow-up from the Framingham Study. JAMA 257: 2176-2180, 1987.

6) Kannel WB, Castelli WP: Cholesterol in the prediction of atherosclerotic disease. New per- spectives based on the Framingham study. Ann Intern Med $90: 85-91,1979$.

7) Benfante R, Reed D : Is elevated serum cholesterol level a risk factor for coronary heart disease in the elderly? JAMA $263: 393-396$, 1990.

8) Castelli WP, Wilson PWF, Levy D, Anderson $\mathrm{K}$ : Cardiovascular risk factors in the elderly. Am J Cardiol 63 : 12H-19H, 1989.

9) Agner E, Hansen PF : Fasting serum cholesterol and triglycerides in a ten-year prospective study in old age. Acta Med Scand $214: 33-41$, 1983.

10) Sekimoto H, Goto $Y$, Goto $Y$, et al: Research committee on familial hyperlipidemia in Japan. Changes of serum total cholesterol and triglyceride levels in normal subjects in Japan in the past twenty years. Jpn Circ J 47 : 1351-1358, 1983.

11) Assmann G, Schulte H : Diabetes mellitus and hypertension in the elderly: Concomitant hyperlipidemia and coronary heart disease risk. Am J Cardiol 63 : 33H-37H, 1989.

12) MacMahon SW, Macdonald GJ : Antihypertensive treatment and plasma lipoprotein levels. The associations in data from a population study. Am J Med 80(Suppl 2A) : 40-47, 1986.

13) Kannel WB: Hypertension, relationship with other risk factors. Drugs 31(Suppl 1) : 1-11, 1986.

14) Kuramoto K, Matsushita S, Shibata H : Effects of hypertension and antihypertensive drugs on cardiovascular complications in the elderly. Jpn Circ J $52: 1-8,1988$.

15) Chobanian AV, Lichtenstein $A H$, Nilakhe V, Haudenschild CC, Drago R, Nickerson C: Influence of hypertension on aortic atherosclereosis in the Watanabe rabbit. Hypertension $14: 203-209,1989$.

16) Lipid Research Clinics Progrm: The lipid research clinics coronary primary prevention trial results: I. Reduction in incidence of coronary heart disease. JAMA $251: 351-364,1984$.

17) Fric $\mathrm{MH}$, Elo O, Haapa $\mathrm{K}$, et al: Helsinki heart study: Primary-prevention trial with 
gemfibrozil in middle-aged men with dyslipidemia: Safety of treatment, changes in risk factors, and incidence of coronary heart disease. New Engl J Med 317 : 1237-1245,
1987.

18）中津千種, 有田幹雄, 友㴊佳明, 他：老年者心筋梗 塞の特徵一急性期臨床像・冠動脈所見・冠危険因子 と長期予後一。旦老医誌 27 : 52-56, 1990.

Abstract

\title{
Cholesterol, Atherosclerosis and Cerebro-Cardiovascular Complications in 3,236 Elderly Autopsy Cases
}

\author{
Kizuku Kuramoto, Seigo Ueda, Satoru Matsushita, Yasuko Suzuki, \\ Yoshihisa Matsumoto and Toru Iijima
}

The effect of serum cholesterol on aortic, cerebral, coronary and femoral atherosclerosis as well as on the incidence of cerebral and myocardial infarctions were analyzed in 3,236 consecutive autopsies in the elderly. Serum cholesterol levels declined over the age of 80 in both genders. The cholesterol levels of females were significantly higher than that of males in each age group from the sixties through the nineties. The increase in serum cholesterol was correlated with the progression of coronary atherosclorosis in both genders, but not with cerebral or femoral atherosclerosis. Slight progression of aortic atherosclerosis was observed when serum cholesterol was over $160 \mathrm{mg} / \mathrm{dl}$. Cholesterol induced progression of coronary atherosclerosis was found in cases

Tokyo Metropolitan Geriatric Hospital with hypertension, but not in the normotensive group. In accordance with the progression of coronary atherosclerosis, the incidence of myocardial infarction increased with an elevation of serum cholesterol levels, and this relationship between myocardial infarction and cholesterol levels was found only in patients with hypertension. No correlation was found between the incidence of cerebral infarction and serum cholesterol levels. It was concluded that hypercholesterolemia in the elderly is a risk factor of myocardial infarction in cases with hypertension, but is not a risk factor of cerebral infarction.

key words: cholesterol, hypertension, atherosclerosis, myocardial infarction, cerebral infarction

(Jpn J Geriat 28: 188-193, 1991) 